\title{
EFEKTIVITAS KONSELING KELOMPOK TEKNIK RELAKSASI UNTUK MEREDUKSI KECEMASAN SISWA MENGHADAPI UJIAN DI SMP PGRI 1 PALEMBANG
}

\author{
Arizona.,M.Pd \\ Universitas PGRI Palembang, arizona.karno@gmail.com \\ Nurlela,M.Pd, Zilla Jannati.,M.Pd \\ Universitas PGRI Palembang, zhila_chubby10@yahoo.co.id
}

\begin{abstract}
Abstrak
Tujuan penelitian ini adalah: (1) untuk mengetahui efektivitas konseling kelompok dan mengurangi kecemasan siswa menghadapi ujian, (2) untuk mengetahui efektivitas model konseling kelompok dengan teknik relaksasi mereduksi kecemasan siswa dalam menghadapi ujian. Jenis penelitian ini adalah penelitian kuantitatif dengan desain penelitian eksperimental, menggunakan desain tes awal (pretest) dan perlakuan akhir (posttest).Penelitian ini melibatkan siswa SMP PGRI 1 Palembang. Langkah-langkah yang diambil adalah: (1) persiapan kelompok eksperimen, (2) pemberian pretest pada kelompok eksperimen (3) memberikan tretment atau perlakuan kepada kelompok eksperimen (4) memberikan post test pada kelompok eksperimen, (5) efektivitas akhir konseling kelompok dengan teknik relaksasi dibantu oleh musik instrumental untuk mengurangi kecemasan siswa menghadapi ujian. Analisis dilakukan menggunakan uji Wilcoxon.Berdasarkan hasil tes lapangan, tingkat kecemasan siswa menghadapi tes telah menurun setelah berpartisipasi dalam kegiatan konseling kelompok dengan teknik relaksasi. Ditunjukkan oleh perubahan tingkat kecemasan siswa yang menghadapi pre-test (evaluasi awal) dan post-test (evaluasi akhir) yaitu sebesar $84 \%$ (pra) hingga $45 \%$ (posting). Hasil uji Wilcoxon diperoleh Asymp.sig. (2-tailed) 0,008 dengan signifikan 5\% $(<0,05)$ sehingga dapat disimpulkan bahwa layanan konseling kelompok dengan teknik relaksasi dibantu oleh musik instrumental efektif untuk mengurangi kecemasan siswa dalam menghadapi ujian.
\end{abstract}

Kata Kunci: konseling kelompok. Relaksasi, musik instrumental, kecemasan

\begin{abstract}
The purpose of this study are: (1) to determine the effectiveness of group counseling and reduce anxiety students face the test, (2) to determine the effectiveness of group counseling models with relaxation techniques to reduce students' anxiety in facing the exam. This type of research is quantitative research with experimental research design, using the initial test design (pretest) and the final treatment (posttest). This research involved PGRI 1 Palembang junior high school students. The steps taken are: (1) preparation of the experimental group, (2) giving the pretest in the experimental group (3) giving tretment or treatment to the experimental group (4) giving post test in the experimental group, (5) the final effectiveness of group counseling with relaxation techniques assisted by instrumental music to reduce the anxiety of students facing exams. The analysis was carried out using the Wilcoxon test. Based on the results of the field test, the level of anxiety students face the test has decreased after participating in group counseling activities with relaxation techniques. Shown by changes in the level of anxiety of students facing the pre-test (initial evaluation) and post-test (final evaluation) that is equal to $84 \%$ (pre) to $45 \%$ (post). Wilcoxon test results obtained Asymp.sig. (2-tailed) of 0.008 with a significant 5\% $(<0.05)$ so that it can be concluded that group counseling services with relaxation techniques assisted by instrumental music are effective to reduce students' anxiety in facing the exam
\end{abstract}

keywords: group counseling. Relaxation, instrumental music, anxiety 


\section{PENDAHULUAN}

Pendidikan itu sangatlah penting bagi bangsa indonesia dan merupakan cita-cita bangsa indonesia untuk mengeluarkan masyarakatnya dari kebodohan. Peranan pendidikan dalam kehidupan diakui sebagai kekuatan kehidupan dimasa yang akan datang. Pendidikan melepaskan individu dari kungkungan pikiran yang membelenggu kehidupan manusia, masalah inilah yang membuat individu sadar akan hak-hak untuk mendapatkan pendidikan agar tidak diperbudak baik oleh pikiran maupun tindakan. Pendidikan dapat membantu memiliki wawasan luas, kemajuan menjadikan dunia menjadi tanpa batas sehingga tidak ada batasan untuk memperoleh ilmu pengetahuan.Hal ini memungkinkan untuk mempelajari tentang adat istiadat dan kebiasaan yang berbeda ataupun peristiwa yang terjadi dibelahan dunia lainnya. Pendidikan telah merubah wajah dunia dan pola pikir masyarakat sekarang, tidak adanya perbedaan antra daerah satu denga daerah lainnya.

Pendidikan adalah suatu proses yang terjadi di dalam kegiatan belajar mengajar dan mengembangkan potensi dirimya secara aktif serta di harapkan peserta didik dapat memiliki kecerdasan spritual,sosial dan emosional, sedangkan fungsi dan tujuan pendidikan nasional itu tercantum pada UU No. 20 tahun 2003 menyatakan bahwa jalur pendidikan itu terdiri dari pendidikan formal, pendidikan non- formal serta pendidikan informal.

Bimbingan dan konseling merupakan bagian dari pendidikan yang bertujuan memandirikan dan mengembangkan potensi diri pada peserta didik atau pemberian bantuan padta didik. Konseling melaksanakan layanan yang terprogram dan terencana yang bersentuhan langsung dengan peserta didik, dengan demikian keberhasilan dalam upaya pemberian bantuan. bantuan yang diberikan kepada peserta didik dapat mencapai sasaran umum dari tujuan pendidikan.

Kecemasan yang berlebihan dalam menghadapi ujian akan mengacaukan emosi, mengganggu siklus tidur, menurunkan nafsu makan dan menurunkan kebugaran tubuh. Hal tersebut bila terjadi dapat mengganggu konsentrasi dalam belajar, sakit secara fisik atau menimbulkan problem dalam berinteraksi sosial.

Gejala kecemasan merupakan komponen utama bagi hampir semua gangguan kejiwaan.Menurut ilmu kedoktoran gangguan kecemasan di bagi menjadi dalam beberapa kelompok, yaitu: gangguan cemas, gangguan cemas menyeluruh, gangguan panik, gangguan phobik dan gangguan obsesif-kompulsif (Hawari 2013:63). Seseorang yang dikatagorikan memiliki kecemasan akan berakibat kepada kehidupan sehari-harinya, aktivitas yang biasa dilakukannya akan menjadi tidak optimal.

Kecemasan merupakan sebuah masalah psikologis yang muncul pada individu yang nampak seperti sikap khawatir terhadap suatu hal yang di presepsikan kurang baik oleh individu. Kecemasan merupakan bentuk kegelisahan, kekhawatiran dan ketakutan terhadap sesuatu yang tidak jelas. Kecemasan itu di alami oleh siapa saja baik itu orang orang dewasa maupun dialami oleh anak ataupun remaja yang masih duduk di bangku sekolah. Bagi peserta didik kecemasan merupakan gangguan emosi yang dapat menghambat proses belajar di sekolah. Dalam hal ini juga peserta didik dirugikan dengan proses pembelajaran yang terhambat yaitu hasil dari proses pembelajaran akan tidak memuaskan dan mungkin tidak sesuai dengan potensi yang dimiliki peserta didik. Semuanya tidak akan optimal.

Kecemasan pada peserta didik dapat berbentuk kecemasan realistik, neurotic atau syaraf bahkan juga kecemasan moral. Karena kecemasan merupakan proses psikis yang sifatnya tidak tampak ke permukaan maka untuk menentukan apakah seorang peserta didik memiliki kecemasan atau tidak, di perlukan penelaahan yang seksama, dengan berusaha mengenali gejala-gejalanya, beserta faktor-faktor yang melatarbelakanginya. Perlu di catat bahwa gejala-gejala kecemasan yang bisa diamati di permukaan hanyalah sebagian kecil saja dari masalah yang sesungguhnya (Gede 2013:488)

beberapa gangguan dengan gejala kecemasan sebagai gejala utama adalah Rasa khawatir yang berlebihan dapat menumbuhkan gejala-gejala kecemasan yang dapat mempengaruhi hidup kita. Sekitar 1 dari 20 orang memiliki gangguan kecemasan pada suatu waktu.Pada saat cemas, kita merasa takut dan tegang. Selain itu kita juga dapat mengalami satu atau lebih gejala fisik yang tidak menyenangkan, seperti denyut jantung yang cepat, jantung berdebar, tubuh terasa sakit, gemetar, berkeringat, mulut kering, nyeri dada, sakit kepala dan nafas cepat (Aldrin 2014:121)

beberapa faktor pemicu timbulnya kecemasan pada diri peserta didik seperti target pencapaian nilai yang ada di dalam kurikulum yang terlalu tinggi, sistem pembelajaran yang kompetitif, pemberian tugas yang sangat padat, serta sistem penilaian yang ketat merupakan faktor penyebab timbulnya kecemasan yang bersumber dari faktor kurikulum. Sementara itu faktor lingkungan peserta didik yang tidak saling mendukung dan membantu dalam menyelesaikan setiap permasalahan yang dihadapi pada saat mengikuti proses pembelajaran di kelas maupun pada saat menyelesaikan pekerjaan rumah tentang mata pelajaran yang dianggap cemas.

Dari berbagai persoalan yang sering muncul dialami oleh siswa telah terpampang pada persoalan-persolan tadi, oleh sebab itu perlu adanya upaya yang penting dalam menangani problema yang sering dialami oleh para siswa dalam menghadapi ujian baik sebelum maupun sesudahnya.

Konseling kelompok dengan teknik teknik Relaksasi untuk mengurangi kecemasan siswa dalam menghadapi ujian menekankan pada asumsi dasar teknik Relaksasi, Asumsi dasar yang mendasari teknik ini adalah bahwa responsi terhadap kecemasan itu dapat dipelajari atau dikondisikan, dan bisa dicegah dengan memberi subtitusi berupa suatu aktivitas yang sifatnya memusuhinya.Prosedur itu digunakan terutama bagi reaksi kecemasan dan penghindaran.Ini mencakup analisa behavioral pertama dari stimulus yang menyebabkan kecemasan dan dibangunnya suatu hirarki dari situasi penghasil kecemasan; kemudian prosedur bersantai diajarkan dan disekenario yang dihayalkan, dari situasi yang dikemukakan dalam suatu urutan dari yang paling 
ringan sampai yang paling mengancam. Stimulus yang menghasilkan kecemasan berkali-kali dipasangkan dengan latihan bersantai sampai hubungan antara stimulus-stimulus serta responsi terhadap kecemasan itu hilang.Kajian-kajian penelitian mengenali Relaksasi yang memperkuat asumsi di atas antara lain: penelitian Otta dan Celestina (2014) didapat hasil bahwa dengan teknik Relaksasi dan teknik perilaku dapat mengurangi kecemasan dalam tes pada siswa di Abia. Selain itu penelitian oleh Ifeanyi (2015) didapat hasil bahwa teknik desensitisasi sistematis efektif dan signifikan dalam mengurangi kecemasan dalam menghadapi tes pada siswa Sekolah Menengah Pertama.

Sehubungan dengan peningkatan mutu pendidikan pada era globalisasi ini pemerinta selalu memperbaiki kenerja guru serta hasil dari proses belajar mengajar tersebut dengan menuntut nilai yang harus tuntas atau melebihi kriteria ketuntasan minimal pada peserta didik hal inilah menimbulkan kecemasan pada siswa dalam menghadapi ujian sekolah.

Focus dalam proses pembelajaran merupakan dasar untuk mengembakan ilmu dan bakat dan minat yang di miliki oleh siswa, namun hasil yang kita peroleh terkadang tidaklah sama dari tujuan yang ingin kita capai dalam proses belajar tersebut, semisalkan rasa cemas karna takut gagal adalah salah satu faktor yang menjadi penghambat proses tersebut.

Hambatan yang muncul salah satunya itu timbul dari dalam diri peserta didik, selain itu bisa faktor dari luar diri siswa dapat mempengaruhi hasil belajar yang ingin di capai, dan apabila hambatan- hambatan yang muncul dalam kegiatan atau proses belajar mengajaar ini tidak di tangulangi atau tidak di perbaiki maka akan muncul masalah lain pada diri peserta didik tersebut.

Teknik relaksasi merupan teknik didalam bimbingan konseling yang di mana teknik ini dapat membantu merelaksasikan diri peserta didik dengan dibantu oleh musik intrumental yang bisa mengurangi tingkat stres pada manusia.

Berdasarkan latar belakang diatas maka untuk itu peneliti ingin sekali melihat keefektifankonseling kelompok Teknik relaksasi untuk mereduksi kecemasan siswa menghadapi ujian sekolah di tingkat sekolah penengah pertama PGRI 1 palembang.

\section{PEMBAHASAN}

\section{Kecemasan}

\section{a. Defenisi kecemasan}

Dalam Kamus Psikologi kecemasan atau kekewatiran diartikan sebagai kegelisahan, kecemasan, kekhawatiran yang kurang jelas atau tidak mendasar. Kartono (2002,:129) Lebih lanjut dia menyebutkan bahwa kecemasan ialah semacam kegelisahan, kekhawatiran, dan ketakutan terhadap sesuatu yang belum pasti kebenarannya,

Pengertian di atas menekankan bahwa penyebab kecemasan adalah sesuatu yang tidak jelas atau sesuatu yang dicemaskan oleh seseorang merupakan sesuatu yang semestinya tidak menyebabkan orang tersebut menjadi cemas.MenurutMenurutAndi Mappiarekecemasanadalah suatu perasaan yang muncul dan dapat membuat perasaan kacauatautidak enakyangmemberikan signal pada individutentang adanyasuatu ancaman atau bahaya namun belumjelas. Menurut J. P. Chaplin, anxiety(kecemasan, kegelisahan) adalah perasaan campuran berisikan ketakutan dan keprihatinan mengenai masa-masa mendatang dan tanpa sebab khusus untuk ketakutantersebut. Menurut Yoseph, kecemasan adalah rasa sudah terkepung, sudahterjepit,dansudahterperangkapolehdandidalambahay a.

Atkinson (2001:212) menyebutkan bahwa kecemasan adalah emosi yang timbul berupa sesuatu tidak menyenangkan, yang ditandai dengan istilah-istilah seperti kekhawatiran, keprihatinan, dan rasa takut yang kadang-kadang dialami oleh seseorang tetapi memiliki tingkatan yang berbeda-beda.

Hurlock (1997: 221) menyimpulkan mengenai kecemasan sebagai keadaan mental yang tidak enak berkenaan dengan sakit yang mengancam atau yang dibayangkan, yang ditandai dengan kekhawatiran atau , ketidaknyamanan, dan prarasaan yang tidak baik, yang tidak dapat dihindari oleh seseorang. Kedua pengertian tersebut nampaknya lebih jelas dalam menggambarkan keadaan yang tidak menyenangkan seperti apa yang bisa disebut sebagai cemas.

Berdasarkan defenisi tersebut kecemasan siswa dalam menghadapi ujian dapat diartikan sebagai keadaan emosi siswa yang tidak menyenangkan atau perasaan yang tidak nyaman pada diri individu, yang dicirikan dengan kegelisahan, ketidak nyamanan, kekhawatiran, ketakutan yang tidak jelas atau tidak pasti kebenarannya yang muncul secara tiba-tibayang dirasakan oleh individu yang merasa akan terjadi hal-hal yang tidak diinginkan ketika siswa menghadapi ujian. Sedangkan bentuk dari kecemasan tersebut, berdasarkan hasil penelitian tentang gejala-gejala kecemasan siswa dalam menghadapi pelajaran dan juga merujuk pada gejala kecemasan secara umum, maka dapat disimpulkan ada tiga bentuk gejala kecemasan siswa dalam menghadapi pelajaran, yaitu, (Indiyani,2010:2):

1. Gejala fisik atau emotionality, seperti tegang saat mengerjakan soal matematika, gugup, berkeringat, tangan gemetar ketika harus menyelesaikan soal matematika atau ketika mulai pelajaran matematika.

2. Gejala kognitif atau worry, seperti : pesimis dirinya tidak mampu mengerjakan soal matematika, khawatir kalau hasil pekerjaan matematikanya buruk, tidak yakin dengan pekerjaan matematikanya sendiri, ketakutan menjadi bahan tertawaan jika tidak mampu mengerjakan soal matematika.

3. Gejala perilaku, seperti : berdiam diri karena takut ditertawakan, tidak mau mengerjakan soal matematika karena takut gagal lagi dan menghindari pelajaran matematika

Kecemasan merupakan hal yang normal terjadi pada setiap individu, reaksi umum terhadap stress kadang 
dengan disertai kemunculan kecemasan.Namun kecemasan itu dikatakan menyimpang bila individu tidak dapat meredam (merepresikan) rasa cemas tersebut dalam situasi dimana kebanyakan orang mampu menanganinya tanpa adanya kesulitan yang berarti.Kecemasan dapat muncul pada situasi tertentu seperti berbicara didepan umum, tekanan pekerjaan yang tinggi, dan menghadapi ujian.

\section{b. Macam-macamKecemasan}

Beberapaahlimenyatakan pendapatnyamengenaimacammacamkecemasan.MenurutGeraldCorey adabentuk kecemasan yang dapat di alami oleh seseorang yaitukecemasan logis atau realistik yaitu rasa cemas yang muncul dari luar diri seseorang dan memiliki tingkat kecemasan sesuai dengan ancaman yang ad,ada juga Kecemasanneurotic yang merupakankecemasan atau ketakutandengan tidak terkendalinyanaluri-naluri yangmenyebabkan seorang melakukansuatutindakanyangbisamendatangkanhukuman baginya. Dan yang ke tiga adalah kecemasanmoralyaitu ketakutanterhadapnurani

sendiri. Freudmembagikecemasanmenjadi

tigajenisyaitukecemasan neurotic(neurotic anxiety), kecemasanrealitas (realityanxiety) dan kecemasanmoral(moralanxiety).Yangdimaksudkecemasa nneurotic (neuroticanxiety)adalah suatubentukpenyakitsaraf,neurosisyang ditandai kecemasan kadarsangat tinggiyangmenetapatauberjangka panjang.Kecemasan

realitas(realityanxiety)adalahbercirikan adanya pertentangan kuat antara dua atau lebih pilihan tindakan untuk pemuasanid danego namuntiap pilihan mengandung konsekuensi negatif ;danketidak mampuan ego membuat pilihan menimbulkan kecemasanrealitas.Dankecemasanmoral

(moralanxiety)adalah adanya pertentangan kuatantara nilai-nilai moral yang diyakini (disertaiketaktanketakutankuatdandosa)namunkuatpuladorongan

iduntukdipenuhi,semnetaraegokurangberfungsi.teori di atasdapatdisimpulkanbahwakecemasandi bagi menjadi tigajenis kecemasan yaitu:kecemasan realistisadalah ketakutan terhadap bahyadari luar diri individu,dan tingkat kecemasannyasesuai dengan derajatancamanyangada.Kecemasanneurotikadalah suatu bentuk kecemasan atau ketakutanterhadap tidak terkendalinyanaluri-naluri yangmenyebabkan seorang melakukan suatu tindakan yangbisamendatangkan hukuman baginya. Dankecemasanmoraladalahkecemasan atau ketakutan terhadaphati nuranisendiri.

\section{Konseling Kelompok}

\section{Pengertian Konseling kelompok}

Defenisi dari konseling kelompok yaitu suatu proses pemberian layanan layanan yang terprogram dan merupakan bagian dari bimbingan dan konseling mana seorang konselor terlibat dalam hubungan di dalam sebuah kelompok dengan sejumlah konseli yang ideal adalah 7 konseli. (Wibowo 2005) mengatakan konseling kelompok adalah suatu proses interpersonal yang menitip beratkan (memusatkan) pada kesadaran berpikir, berorientasi pada kenyataan, ada rasa saling mempercayai, ada pengertian, penerimaan dan bantuan. (Ohlsen dalam Wibowo,2005) menyatakan konseling kelompok merupakan pengalaman terapeutik bagi orangorang yang tidak mempunyai masalah-masalahemosional yang serius. Dalam konseling kelompok ada hubungan antara konselor dengan anggota kelompok penuh rasa penerimaan, kepercayaan dan rasa aman.Dalam hubungan ini anggota kelompok (konseli) belajar menghadapi, mengekspresikan dan menguasai perasaan-perasaan atau pemikiran-pemikiran yang mengganggunya yang merupakan masalah baginya.

Konseling kelompok adalah suatu proses antar pribadi yang dinamis yang berpusat pada pemikiran dan prilaku yang sadar dan melibatkan fungsi-fungsi terapi seperti sifat permisif, berorientasi pada kenyataan, katarsis, saling mempercayai, saling memperlakukan dengan mesra, saling pengertian, saling menerima dan saling mendukung (Gazda et al dalam Wibowo, 2005).

Wibowo (2005:18) konseling kelompok adalah suatu proses interpersonal yang dinamis dan menitik beratkan atau memusatkan pada kesadaran berfikir dan tingkah laku, melibatkan fungsi terapeutik, berorientasi pada kenyamanan, ada rasa saling percaya, pengertian, penerimaan dan bantuan.

Berdasarkan beberapa teori yang telah dipaparkan kesimpulannya adalah konseling kelompok merupakan suatu proses layanan membantu sekelompok konseli yang dinamis dengan menitikberatkan kepada kognitif dan perilaku sadar dengan melibatkan fungsi terapeutik, berorientasi pada kenyamanan dengan membangun rasa saling percaya, penerimaan, pengertian dan bantuan.permasalahan yang di maksud disini terkait dengan kecemasan siswapeserta didik yang masih rendah dan hal ini penting untuk ditingkatkan.

\section{Tujuan Konseling Kelompok}

Tujuan Konseling kelompok adalah pengembangan diri, pembahasan dan pemecahan masalah pribadi yang dialami oleh masing-masing anggota kelompok, agar terhindar dari masalah, dan masalah diselesaikan dengan cepat melalui bantuan anggota kelompok yang lain (Wibowo,2005:20)

Menurut Corey (2012: 33) tujuan dilaksanakannya layanan konseling kelompok meliputi:

Membantu individu mencapai perkembangan perilaku yang positif dan mencapai keterampilan interpersonal yang efektif.

Memberdayakan proses kelompok untuk memfasilitasi modifikasi perilaku dalam hal ini adalah kecemasan menghadapi Ujian. .

Membantu anggota kelompok memperoleh dan belajar perilaku baru yang dapat diaplikasikan pada kehidupan sehari-harinya.

Layanan BK kelompok adalah berkembangnya kemampuan sosialisasi siswa, khususnya kemampuan komunikasi peserta layanan. Selain itu yang dimaksudkan adalah menyelesaikan masalah konseli 
dengan memanfaatkan atau menggunakan dinamika kelompok. Karena sejatinya tujuan khusus konseling kelompok pada dasamya terletak pada pembahasan masalah pribadi individu peserta kegiatan lavanan.( Prayitno (2004: 2-4) Melalui layanan kelompok yang intensif dalam upaya pemecahan masalah tersebut para peserta memperoleh dua tujuan sekaligus, yaitu:

1. Terkembangkannya perasaan, pikiran, persepsi, wawasan dan sikap terarah kepada tingkah laku khususnya dalam persosialistis/komunikasi.

2. Terpecahkannya masalah individu yang bersangkutan dan diperolehnya imbasan pemecahan masalah tersebut hagi individ-individu lain peserta pada layanan konseling kelompok khususnya.

\section{Teknik Relaksasi}

\section{Defenisi Relaksasi}

Relaksasi adalah suatu teknik yang dapat membantu seseoarang dalam menyelsaikan masalahnya dan juga merupakan salah satu intervensi psikologis yang dapat diterapkan pada gangguan psikomatis, demikian pula untuk gangguan psikologis seperti phobia dan stres. Relaksasi sudah terbukti cocok untuk mengurangi rasa panik, cemas yang berlebihan atau gangguan panik karena lebih dapat mengontrol keadaan dan fungsi psikologis dibandingkan terapi kognitif (Kazdin, 1994; Beck, Stanley, Baldwin, Deagle, dan Averill, 2001).Relaksasi adalah suatu metode yang di gunakan untuk melawan stres, mengatas kemarahan, mengurangi kecemasan, dan juga dapat mengurangi kecemasan, kecemasan menghadapi Ujian.dan pemecahan masalah ( keith F. Bell : 2011)

Hewitt dalam Qurrotun Ayu. Sumbodo Prabowo, Dewi Setyorini (2013) menjabarkan bahwalatihan relaksasi dapat menghilangkan ketegangan pada fisik dan psikis serta pat dmembuka kesadaran(mereduksi kesehatan dan melindungi dari penyakit, menjaga danmenggabungkan energi, mencapai keahlian psikofisikal, dan mereduksi keadaan keseimbangan psikofisikal).

Menurut Burn dalam Qurrotun Ayu. (2013) mendefinisikan bahwakelebihan yang diperoleh dari latihan relaksasi diantaranya ialah membuat individu lebih mampu menghindari reaksi yangberlebihan karena adanya stres, dan mengurangi kemungkinan gangguan yang berhubungan dengan stres.

Relaksasi adalah suatu teknikmengurangi ketegangan dan mengembalikan keseimbangan baik pikiran maupun tubuh. Teknik relaksasi sangat penting untuk mengurangi stres. Karena pikiran merupakan awal darii perkembangan banyak penyakit, orang perlu penangkal pertempuran stres.Bahkan, relaksasi mungkin menjadi salah satu faktor yang paling penting dalam menjaga kesehatan tubuh dan pikiran. Relaksasi yang profesional sangat penting untuk kesehatan dan disarankan terapis harus menggunaan teknik relaksasi berbantuan musik instrumental untuk mengelola stress, stres tidak hanya dalam kehidupan sehari-hari tetapi juga stres yang disebabkan oleh kondisi kesehatan tiap pasien. Teknik relaksasi berbantuan musik instrumental dapat menguntungkan baik kesehatan psikologis dan fisik.
Menurut Nietzel dan Berstein (1987) teknik relaksasi merupakan teknik yang dapat di pelajari untuk menghilangakan rasa takut,cemas, khawatir dengan mengkondisikan dan relaksasi dapat menghilangkan fobia dengan memberikan stimulus-stimulus pada individu yang mengalami fobia.

Menurut Wolpe (dalam Gerald Corey, 2007:210) suatu respon yang telahdi kembangkan yakni relaksasi,kecemasan yang secara sistematis dapat di kelompokanmenurut aspek-aspek dari situasi yang mengancam. Relaksasi merupakan teknik yang sangat tepat diberikan untuk nenyembukan fobia, kekhawatiran dan rasa takut yang berlebihan. Teknik ini bisa diterapkan secara tepat disegala situasi penghasil kecemasan, mencakup situasi dari luar diri individu, ketakutan terhadap ujian, kecemasan yang muncul dari pikiran, serta pada penderita kelainan orientasi seks.

Teknik relaksasi berbantuan musik instrumental yang bermanfaat untuk pikiran dan tubuh.Ada beberapa teknik relaksasi berbantuan musik instrumental yang mempromosikan baik kesehatan psikologis dan fisik.Beberapa teknik yang diajarkan dan dilakukan oleh para ahli.Ada juga teknik yang dapat Anda gunakan sendiri.

\section{PENUTUP}

\section{Simpulan}

Berdasarkan hasil analisis data, mulai dari tahap penelitian pendahuluan sempai pada uji coba intrumen dapat dirumuskan beberapa kesimpulan sebagai berikut:

Layanan konseling kelompok di SMP PGRI 1 Palembang pelaksanaannya sudah sesuai tahapan, teknik yang digunakan adalah teknik relaksasi.

\section{Saran}

Berdasarkan simpulan hasil penelitian, maka beberapa saran yang dapat diberikan antara lain:

Sehubungan dengan pentingnya masalah Kecemasan, penangananya dengan menggunakan layanan konseling kelompok menggunakan teknik relaksasi berbasis musik intrumental dapat diprogramkan secara periodik terutama terhadap siswa-siswi yang skala Kecemasan masuk pada katergori rendah.

. Pengguanaan model Kkp menggunakan teknik relaksasi berbasis musik intrumental untukmereduksi Kecemasan siswa tidak hanya terbatas guru BK dalam memberikan layanan konseling kelompok kepada siswa dalam satu sekolah.

\section{DAFTAR PUSTAKA}

Alwisol, 2005.Psikologi kepribadian. UMM Press\

Azwar, S. 2012. Penyusunan Skala Psikologi. Edisi 2. Yogyakarta: Pustaka Pelajar.

Bandura Albert, 1995. Kecemasan in Changing in societies.USA. Cambrige University Press

Bell Keith. 2011. Berpikir Juara. Satlak Prima Utama Muda 
Borg, W.R., Gall, M.D. 2003. Educational Research: An Intruduction. London: Longman, Inc.

Corey, G. (2012). Theory \& Practice of Group Counseling (Gerald Corey Eight Edition).Canada: By Nelson Education, Ltd.

Corey. 2011. Becoming a helper sixth edition. USA,Broks/Cole, Cengage Learning

Djohan, 2009.Psikologi Musik. Yogyakarta, Best Publisher

Djohan, 2006, Terapi Musik; Teori dan Aplikasi, Yogyakarta. GalangPress

Feist,Jess\& Gregory J.Feist. 2010. Teori Kepribadian: Buku 2, Edisi 7. Jakarta: Salemba Humanika.

Feist,Jess\& Gregory J.Feist. 2013. Teori Kepribadian: Buku 1, Edisi 7. Jakarta: Salemba Humanika.

Gibson, R.L. at all. 2011. Bimbingan dan Konseling. Yogyakarta: Pustaka Pelajar.

Gufron, N.M \& Risnawita, R.S. 2010.Teori-teori Psikologi.Jogjakarta: Ar-Ruzz Media.

Hakim. Lauster, P. 1997. Test Kepribadian( terjemahan Cecilia, G. Sumekto ). Yokyakarta.Kanisius.

Hastomi dan Sumaryati. 2012. Terapi Musik.javalitera

Jesus, N. G. \& Raquet F. 2013.Classroom Manajement Kecemasan and Burnout: A Multivariate Metaanalysis. Tersedia di www.springer.com

Judith H. Wakim, EdD, RN, CNE, Stephanie Smith, MSN, Crna, Cherry Guinn, EdD, RN, 2010.The efficacy of Music therapy, Amarecan society of perianesthesia nurse

Kurnanto, E. (2013). Konseling Kelompok. Bandung: Alfabeta.

M. Owen et al. 2015. Group CBT for psychosis: A longitudinal, controlled trial with inpatients.Behaviour Research and Therapy 65 76-85

Madhusudan Singh Solanki, Mehnaz Zafar, Rajesh Rastogi.2012.Music as a therapy: Role in psychiatry, Elsevier

Moleong, L.J. 2009.Metodologi Penelitian Kualitatif. Bandung: PT. Remaja Rosda Karya.

Natawidjaja, Rochman.

(2009). Konseling Kelompok,konsep Dasar dan pendekatan . Bandung: Rizqi Press.
Noor Azizah, Ana Zumrotun Nisak, FaniaNurul Khoirun Nisa, 2015.Teknik relaksasi berbasis musik instrumental Nafas Dalam Dan Terapi Musik Sebagai Upaya Penurunan Intensitas Nyeri Haid (Dysmenorrhea), University Research ColoquiumISSN 2407-918

Nursalim, 2013.Strategi dan intervensi konseling.Jakarta. Akademia Permata

Prayitno.2004. Layanan Bimbingan dan Konseling Kelompok.(L6 \& L 7). Padang: Jurusan Bimbingan dan Konseling FIP UNP.

Prayitno \& Emyati, Erman. 2004. Dasar-dasar Bimbingan dan Konseling. Jakarta: PT. Rineka Cipta.

Qurrotun Ayu. Sumbodo Prabowo, Dewi Setyorini,2013.Efektivitas terapi relaksasi untuk mengurangi tingkat stres kerja bagian penjualan pt. sinarsosro semarang, Kajian Ilmiah Psikologi No 1, Vol. 2,

Robert, C., et al. 2006. Group Counseling Concept and Procedures 4th ed. USA. Taylor \& Francis Group, LLC.

Sugiyono. 2011. Metode Penelitian Kombinasi (Mixed Methodes). Bandung: Alfabeta.

.2012. Metode Penelitian Pendidikan, pendekatan Kuantitatif, kualitatif dan $R \& D$. Bandung: Alfabeta

-2014.Pengaruh Dan Efektifitas Cognitive Behavioral Therapy (Cbt) Berbasis Komputer Terhadap Klien Cemas Dan Depresi.Volume 1.E-Journal Widya Kesehatan Dan Lingkungan

Undang-Undang No. 20Tahun 2003. Jakarta: Kemendikbud Republik Indonesia.

Widarso, W. 2005. Sukes Membangun Rasa Percaya Diri.Jakarta:Gramedia Widiasarana Indonesia.

Winkel, W.S. 2006. Bimbingan dan Konseling di Institusi Pendidikan. Jakarta : Grasindo.

Winkel, W.S dan Hastuti, S. 2004. Bimbingan Dan Konseling Di Institusi Pendidikan. Yogyakarta: Media Abadi.

Yustinus, S. 2006. Kesehatan Mental 3. Yogyakarta: Kanisius.

Yusuf, S dan Nurihsan, J. 2010.Landasan Bimbingan dan Konseling. Bandung: Rosda Karya. 